\title{
Tick-borne rickettsioses in Brazil: what lessons can be learned from the COVID-19 pandemic
}

\author{
Doenças transmitidas por carrapatos no Brasil: lições a serem aprendidas da \\ pandemia de COVID-19 \\ João Luiz Horacio Faccini' ${ }^{1}$; ; Hermes Ribeiro Luz²; Douglas McIntosh'; Marcelo Bahia Labruna ${ }^{3}$ \\ 'Departamento de Parasitologia Animal, Instituto de Veterinária, Universidade Federal Rural do Rio de Janeiro - UFRRJ, Seropédica, RJ, Brasil \\ ${ }^{2}$ Programa de Doutorado em Biotecnologia - Rede Nordeste de Biotecnologia - RENORBIO, Departamento de Patologia, Centro de \\ Ciências Biológicas e da Saúde, Universidade Federal do Maranhão - UFMA, São Luís, MA, Brasil \\ ${ }^{3}$ Departamento de Medicina Veterinária Preventiva e Saúde Animal, Faculdade de Medicina Veterinária e Zootecnia, Universidade de \\ São Paulo - USP, São Paulo, SP, Brasil
}

How to cite: Faccini JLH, Luz HR, McIntosh D, Labruna MB. Tick-borne rickettsioses in Brazil: what lessons can be learned from the COVID-19 pandemic. Braz J Vet Parasitol 2020; 29(3): e012220. https://doi.org/10.1590/S1984-29612020056

\begin{abstract}
In this commentary, the authors highlight the importance of basic research in the field of public health regarding the recent pandemic Covid-19, using tick-borne rickettsioses as an example. In addition, they alert politicians, government officials and managers of research funding agencies to increase the allocated financial resources to enhance basic research on public health in Brazil.
\end{abstract}

Keywords: Basic research, public health, financial support, Brazil.

\section{Resumo}

Neste comentário, os autores destacam a importância da pesquisa básica em saúde pública em relação à recente pandemia Covid-19, usando-se as riquetsioses transmitidas por carrapatos como exemplo. Além disso, alertam políticos, funcionários do governo e gerentes de agências de fomento à pesquisa para aumentar os recursos financeiros alocados a fim de aprimorar a pesquisa básica em saúde pública no País.

Palavras-chave: Pesquisa básica, saúde pública, financiamento, Brasil. 


\section{The Fate of Basic Research in Public Health in Brazil}

The on-going pandemic (COVID-19), caused by the coronavirus SARS-CoV-2, has dramatically impacted humanity from public health and economic perspectives. Viewed as a medical topic, COVID-19 represents a near perfect example of what public health specialists have predicted for decades, namely a serious international epidemic caused by a pathogen previously unknown to cause human disease (Xu, 2019). Rapid transmission, elevated levels of hospitalization and case fatality levels of between 1.3 to $15 \%$ have combined to hard-hit all continents, except for Antarctica (McAleer, 2020), with more than 292,000 deaths recorded to date, according to John Hopkins University (2020). From an economic viewpoint, forecasts made by the World Bank and the United Nations Department of Economics and Social Affairs point to an impending worldwide recession, resulting in the loss of millions of jobs, with low to middle income countries likely to be most affected. Although, the etiology of COVID-19 is firmly established, our knowledge concerning its origin, pathophysiology, pathology, treatment, or possible means of prevention is incipient. A hypothesis raised by Asian scientists (Luk et al., 2019), based upon a retrospective analysis of the SARS epidemic that affected 26 countries in 2003, pointed to bats as the natural hosts/reservoir and probable origin of the transmission chain, which remains undetermined, to humans - therefore constituting a ZOONOSIS.

Several species of bats have been shown as infected with SARS-like - coronaviruses (Wong et al., 2019) including a coronavirus very similar to SARS-CoV-2; indeed, SARS-CoV-2 is one among dozens of members of the family Coronaviridae known to cause respiratory or intestinal infections in humans and other animals (Decaro \& Lorusso, 2020) and is a representative of the more than 200 species of viruses isolated from or detected in bats (Moratelli \& Calisher, 2015). Several viruses with zoonotic potential have been identified in various orders of wild animals, and are transmitted to humans by rodents via contact with contaminated urine or feces e.g. hantavirus, while others associated with a variety of encephalitic conditions, are transmitted indirectly to humans from infected animals e.g. West Nile fever, with the involvement of arthropod vectors including mosquitoes or ticks. Interestingly, it was recently demonstrated that "[...] the number of human-infecting viruses increases proportionately to the total number of viruses maintained by each reservoir group, which is in turn explained by the number of animal species within each group [...]" (Mollentze \& Streicker, 2020, p. 1). This finding supports a host-neutral explanation for observed variation in the number of zoonoses among animal groups, such that "[...] traits of animal orders are unlikely to produce viruses that disproportionately threaten humans [...]" (Mollentze \& Streicker, 2020, p. 1). Investigations as that are most often classified in academic circles and by public or private granting agencies as "basic research", therefore, resulting in their frequently being considered as lower-priority, relative to "applied research", by those financial support organizations. Moreover, in developing or underdeveloped countries basic research propositions often fail to attract funding based on the allegation of lack of resources or, more frustratingly, due to lack of interest among government officials and politicians.

Tick-borne Rickettsioses have long been known on all continents. Although, much less efficient in terms of dissemination when compared to air-borne viral diseases such as COVID-19, they clearly represent a significant public health concern worldwide (Parola et al., 2013). Results obtained by researchers from Universidade Federal Rural do Rio de Janeiro (UFRRJ), Universidade Federal do Maranhão (UFMA) and Universidade de São Paulo (USP) have demonstrated a significant and growing number of tick-borne rickettsiae occurring in Brazil, in addition to Rickettsia rickettsii, which causes Brazilian Spotted Fever and the epidemiology of which is well known with emphasis on the natural host - the capybara - and the tick vector - Amblyomma sculptum (formely Amblyomma cajennense, in part) (Luz et al., 2019a). To date, 12 rickettsial agents, including accepted and Candidatus species and strains have been identified in Brazilian territories either in questing ticks or ticks associated with wild birds and mammals, including humans (Luz et al., 2018, 2019b; Peckle et al., 2019). Among these are Rickettsia parkeri, and genetically related strains (Silveira et al., 2007; Peckle et al., 2019) some of which may cause less severe disease in humans and are almost always associated with the development of an inoculation eschar. Perhaps not coincidentally, but certainly intriguingly, South America is recognized as the continent with the lowest diversity of tick-borne diseases in the world (Parola et al., 2013; Rodriguez-Morales et al., 2018), despite its extensive biodiversity (Sen Nag, 2018). The diversity of rickettsiae with zoonotic potential occurring worldwide (Parola et al., 2013), could be viewed as analogous to the diversity of wildlife viruses described to date (Moratelli \& Calisher, 2015). Thus, we believe it is both appropriate and necessary to alert legislators, responsible for public policies and the decision makers within public and private development agencies as to the importance of expanding basic research activities on the occurrence and significance of potential pathogens, including Rickettsia, in wild animals. Such investments are essential in order to determine and predict their possible involvement in ZOONOSES, resulting from increased contact with humans as new frontiers of colonization are established based upon motives including increasing food production, the provision of improved living conditions and the expansion of industrial development. 


\section{Acknowledgements}

The authors have been financially supported by CNPq (JLH Faccini, MB Labruna), FAPERJ (JLH Faccini, D McIntosh) and FAPESP (HR Luz, MB Labruna).

\section{References}

Decaro N, Lorusso A. Novel human coronavirus (SARS-CoV-2): a lesson from animal coronaviruses. Vet Microbiol 2020; 244: 108693. http://dx.doi.org/10.1016/j.vetmic.2020.108693. PMid:32402329.

John Hopkins University. COVID-19 map -Johns Hopkins Coronavirus Resource Center [online]. Baltimore: John Hopkins University; 2020 [cited 2020 May 13]. Available from: https: //coronavirus.jhu.edu/map.html

Luk HK, Li X, Fung J, Lau SK, Woo PC. Molecular epidemiology, evolution and phylogeny of SARS coronavirus. Infect Genet Evol 2019; 71: 21-30. http://dx.doi.org/10.1016/j.meegid.2019.03.001. PMid:30844511.

Luz HR, Costa FB, Benatti HR, Ramos VN, de A Serpa MC, Martins TF, et al. Epidemiology of capybara-associated Brazilian spotted fever. PLoS Neg/ Trop Dis 2019a; 13(9): e0007734. http://dx.doi.org/10.1371/journal.pntd.0007734. PMid:31490924.

Luz HR, Muñoz-Leal S, de Carvalho WD, Castro IJ, Xavier BS, Toledo J, et al. Detection of "Candidatus Rickettsia wissemanii" in ticks parasitizing bats (Mammalia: Chiroptera) in the northern Brazilian Amazon. Parasitol Res 2019b; 118(11): 3185-3189. http:// dx.doi.org/10.1007/s00436-019-06442-3. PMid:31473856.

Luz HR, Silva-Santos E, Costa-Campos CE, Acosta I, Martins TF, Muñoz-Leal S, et al. Detection of Rickettsia spp. in ticks parasitizing toads (Rhinella marina) in the northern Brazilian Amazon. Exp Appl Acarol 2018; 75(3): 309-318. http://dx.doi.org/10.1007/s10493018-0270-y. PMid:29846852.

McAleer M. Prevention is better than the cure: risk management of COVID-19.J Risk Financial Manag 2020; 13(3): 46. http://dx.doi. org/10.3390/jrfm13030046.

Mollentze N, Streicker DG. Viral zoonotic risk is homogenous among taxonomic orders of mammalian and avian reservoir hosts. Proc Natl Acad Sci USA 2020; 117(17): 9423-9430. http://dx.doi.org/10.1073/pnas.1919176117. PMid:32284401.

Moratelli R, Calisher CH. Bats and zoonotic viruses: can we confidently link bats with emerging deadly viruses? Mem Inst Oswaldo Cruz 2015; 110(1): 1-22. http://dx.doi.org/10.1590/0074-02760150048. PMid:25742261.

Parola P, Paddock CD, Socolovschi C, Labruna MB, Mediannikov O, Kernif T, et al. Update on tick-borne rickettsioses around the world: a geographic approach. Clin Microbiol Rev 2013; 26(4): 657-702. http://dx.doi.org/10.1128/CMR.00032-13. PMid:24092850.

Peckle M, Luz HR, Labruna MB, Serpa MCA, Lima S, Maturano R, et al. Multi-locus phylogenetic analysis groups the New World bacterium Rickettsia sp. strain ApPR with the Old World species R. africae; proposal of Candidatus Rickettsia paranaensis. Ticks Tick Borne Dis 2019; 10(6): 101261. http://dx.doi.org/10.1016/j.ttbdis.2019.07.005. PMid:31337544.

Rodriguez-Morales AJ, Bonilla-Aldana DK, Idarraga-Bedoya SE, Garcia-Bustos JJ, Cardona-Ospina JA, Faccini-Martínez ÁA. Epidemiology of zoonotic tick-borne diseases in Latin America: are we just seeing the tip of the iceberg? F1000 Res 2018 ; 7: 1988. http://dx.doi.org/10.12688/f1000research.17649.1. PMid:31489178.

Sen Nag O. The Five Biodiversity Hotspots of South America [online]. Quebec: WorldAtlas; 2018 [cited 2020 Apr 28]. Available from: https://www.worldatlas.com/articles/the-five-biodiversity-hotspots-of-south-america.html

Silveira I, Pacheco RC, Szabó MP, Ramos HG, Labruna MB. Rickettsia parkeri in Brazil. Emerg Infect Dis 2007; 13(7): 1111-1113. http://dx.doi.org/10.3201/eid1307.061397. PMid:18214195.

Wong ACP, Li X, Lau SK, Woo PC. Global epidemiology of bat coronaviruses. Viruses 2019; 11(2): 174. . http://dx.doi.org/10.3390/ v11020174. PMid:30791586.

Xu J. Reverse microbial etiology: a research field for predicting and preventing emerging infectious diseases caused by an unknown microorganism. J Biosaf Biosecur 2019; 1(1): 19-21. http://dx.doi.org/10.1016/j.jobb.2018.12.005. PMid:32501431. 